\title{
Article \\ Roles of High Osmolarity Glycerol and Cell Wall Integrity
Pathways in Cadmium Toxicity in Saccharomyces cerevisiae
}

\author{
Yunying Zhao ${ }^{1}$, Shiyun $\mathrm{Li}^{2}$, Jing Wang ${ }^{3}{ }^{\circledR}$, Yingli Liu ${ }^{3}$ and Yu Deng ${ }^{1, *}$ \\ 1 National Engineering Laboratory for Cereal Fermentation Technology (NELCF), School of Biotechnology, \\ Jiangnan University, 1800 Lihu Road, Wuxi 214122, China; yunyingzhao@jiangnan.edu.cn \\ 2 Jiangsu Provincial Research Center for Bioactive Product Processing Technology, Jiangnan University, \\ 1800 Lihu Road, Wuxi 214122, China; 7180201005@stu.jiangnan.edu.cn \\ 3 China-Canada Joint Laboratory of Food Nutrition and Health (Beijing), Beijing Technology and Business \\ University, Beijing 100048, China; wangjing@th.btbu.edu.cn (J.W.); liuyingli@th.btbu.edu.cn (Y.L.) \\ * Correspondence: dengyu@jiangnan.edu.cn
}

Citation: Zhao, Y.; Li, S.; Wang, J.; Liu, Y.; Deng, Y. Roles of High Osmolarity Glycerol and Cell Wall Integrity Pathways in Cadmium Toxicity in Saccharomyces cerevisiae. Int. J. Mol. Sci. 2021, 22, 6169. https://doi.org/10.3390/ ijms22126169

Academic Editor: Reinhard Dallinger

Received: 6 May 2021

Accepted: 4 June 2021

Published: 8 June 2021

Publisher's Note: MDPI stays neutral with regard to jurisdictional claims in published maps and institutional affiliations.

Copyright: () 2021 by the authors. Licensee MDPI, Basel, Switzerland. This article is an open access article distributed under the terms and conditions of the Creative Commons Attribution (CC BY) license (https:// creativecommons.org/licenses/by/ $4.0 /)$.

\begin{abstract}
Cadmium is a carcinogen that can induce ER stress, DNA damage, oxidative stress and cell death. The yeast mitogen-activated protein kinase (MAPK) signalling pathways paly crucial roles in response to various stresses. Here, we demonstrate that the unfolded protein response (UPR) pathway, the high osmolarity glycerol (HOG) pathway and the cell wall integrity (CWI) pathway are all essential for yeast cells to defend against the cadmium-induced toxicity, including the elevated ROS and cell death levels induced by cadmium. We show that the UPR pathway is required for the cadmium-induced phosphorylation of HOG_MAPK Hog1 but not for CWI_MAPK Slt2, while Slt2 but not Hog1 is required for the activation of the UPR pathway through the transcription factors of Swi6 and Rlm1. Moreover, deletion of HAC1 and IRE1 could promote the nuclear accumulation of Hog1, and increase the cytosolic and bud neck localisation of Slt2, indicating crucial roles of Hog1 and Slt2 in regulating the cellular process in the absence of UPR pathway. Altogether, our findings highlight the significance of these two MAPK pathways of HOG and CWI and their interrelationship with the UPR pathway in responding to cadmium-induced toxicity in budding yeast.
\end{abstract}

Keywords: Saccharomyces cerevisiae; cadmium toxicity; unfolded protein response (UPR); ER stress; reactive oxygen species (ROS); cell death; Hog1; Slt2

\section{Introduction}

Cadmium (Cd) is a toxic heavy metal that can induce oxidative stress, cell death (apoptosis), DNA damage and even cancer in humans [1,2]. The main mechanism of the generation of reactive oxygen species (ROS) induced by $\mathrm{Cd}$ is to deplete cells' antioxidant defences or to displace the redox-active metals from some essential enzymes [3-5]. Increased intracellular ROS levels can cause endoplasmic reticulum stress (ER stress), cell death (apoptosis) and DNA damage [6,7]. In budding yeast, the cadmium-induced cell death needs the caspase Yca1 and is dependent on glucose [8]. In addition, Cd-induced cell death is also mediated by the calcium signalling pathway [9]. For instance, Cd lead to a rapid elevation of the cytosolic calcium and the perturbation of ER calcium homeostasis can cause ER stress and, thus, induce cell death [10,11].

The main function of ER is to maintain a suitable environment for protein modification, protein folding, calcium homeostasis as well as ER-associated protein degradation (ERAD) and protein folding $[12,13]$. In yeast, the unfolded protein response (UPR) is trigged by the transmembrane sensor Ire1p when the increasing unfolded or misfolded proteins were accumulated in ER in response to ER stress [14]. The RNase activity of Ire1 was activated after its own oligomerization and autophosphorylation in response to ER stress. Activated Ire1 splices the intron from the mRNA of the transcription factor Hac1p, which was then efficiently translated and to activate the downstream target genes involved in 
protein folding, protein trafficking, cell wall architecture, ER-associated protein degradation (ERAD) and lipid biosynthesis $[15,16]$. In human cells, accumulated evidence has suggested that UPR was associated with occurrence of tumors [17,18]. ER stress is also accompanied by increased ROS generation, which then leads to cell apoptosis (death) through noncanonical protein kinase RNA-like endoplasmic reticulum kinase (PERK)-dependent translational control [19]. In addition, ER also serves as a major target of cadmium toxicity. In Saccharomyces cerevisiae, cadmium causes ER stress and activates UPR mainly through inducing the splicing of $\mathrm{HAC} 1 \mathrm{mRNA}$ and promoting Ire1 protein to cluster in distinct foci [20,21]. Similarly, mutants for HAC1 and IRE1 were both sensitive to cadmium, indicating the UPR is also essential for cadmium tolerance [22].

From a functional screen using homozygous diploid deletion mutant library, the mitogen-activated protein kinase signalling pathways of the high osmolarity glycerol (HOG) pathway and the cell wall integrity (CWI) pathway were first identified to be involved in the tunicamycin-induced UPR [23]. In addition, the HOG pathway and the CWI pathway were also essential for cadmium tolerance [22,24]. Meanwhile, phosphorylation activation of Hog1 and Slt2 could be induced by cadmium [25,26]. Hog1 plays crucial roles in regulating cellular processes in response to osmotic stress and cell wall stress [27-29]. Hog1 is activated by ER stress in a UPR dependent manner, and this process is mediated by Ssk1 branch [30]. They also found that the phosphorylated Hog1 could help the ER regain homeostasis through promoting HAC1 mRNA splicing in the late stage of ER stress. Persistent ER stress induces autophagy in the late phase and this process is accompanied with the kinetics of Hog1 phosphorylation, which regulate the stability of a critical autophagy protein Atg8 [30-32].

The yeast cell wall is essential for cells to protect against osmotic shock and mechanical stress, to establish and maintain cell shape, and to provide a scaffold for the cell-surface proteins [33]. The cell wall integrity (CWI) signalling pathway control these processes in response to various environmental challenges, such as heat stress, hypo-osmotic shock, oxidative stress, DNA-damaging agents and cell wall stress [33]. ER stress drugs, such as tunicamycin and dithiothreitol, could activate the CWI signalling pathway in a UPR independent manner [23,34,35]. It has been reported that tunicamycin-induced activation of Slt2 is mainly triggered by the Wsc1 sensor and the transcription factor Slm1, while the cell wall perturbing agents Calcofluor white (CFW) activated UPR via the putative cell wall stress receptors Mid2 and the transcription factor Swi6 [36,37]. Genetic phenotype analysis indicated that mutants for IRE1 and SLT2 were all sensitive to CFW and tunicamycin $[23,36]$. The MAPK Slt2 was also involved in the ER stress surveillance (ERSU) pathway that could delay ER inheritance and cytokinesis by altering the septin complex in response to ER stress, although this process is independent of the UPR pathway [35].

Although the roles of Hog1 and Slt2 in regulating UPR in response to ER stress and cadmium, the specific mechanism of these two MAPKs in the cadmium toxicity remains unclear. In this study, we showed that the three pathways of UPR, HOG and CWI were all required for cell survival in response to cadmium toxicity. We observed that the phosphorylation activation of Hog1 required the UPR pathway, while the activation of the UPR pathway needed Slt2. In addition, the results of subcellular localisation analysis demonstrated that Ire1 and Hac1 could regulate the localisation of both Hog1 and Slt2. These findings suggest that the UPR, HOG and CWI pathways are closely related and interact with each other in helping a cell to reduce cadmium toxicity. Our data sheds light on the specific mechanism of cadmium-induced toxicity in budding yeast.

\section{Results}

\subsection{UPR Pathway Is Required for Cadmium-Induced Activation of Hog1}

To further analyse the role of the HOG pathway in cadmium-induced toxicity, we first tested the growth ability of the mutants involved in the HOG pathway in response to cadmium stress. Since cadmium can cause ER stress in yeast cells [20,21], we also chose the ER stress drug, tunicamycin (TM), which triggers ER stress by inhibiting N-linked 
glycosylation [23]. As shown in Figure 1A, the mutants of two components of the HOG pathway, Hog1 and Pbs2, were both sensitive to Cd and TM, which was consistent with the results reported previously $[22,33]$. It was reported previously that both the $\operatorname{Sin} 1$ and Sho1 branches of the HOG pathway are needed for phosphorylation of Hog1 in response to Cd stress, while Hog1 is phosphorylated only through the Sln 1 branch following DTT or TM treatment $[26,30]$. Consistent with these observations, we found that $h \circ g 1 \Delta, p b s 2 \Delta$ and ssk1 $\Delta$ (Sln1 branch) mutants were both sensitive to $\mathrm{Cd}$ and TM, while ste20 $\Delta$ and ste50 $\Delta$ mutants in Sho1 branch were only sensitive to Cd (Figure 1A).

A

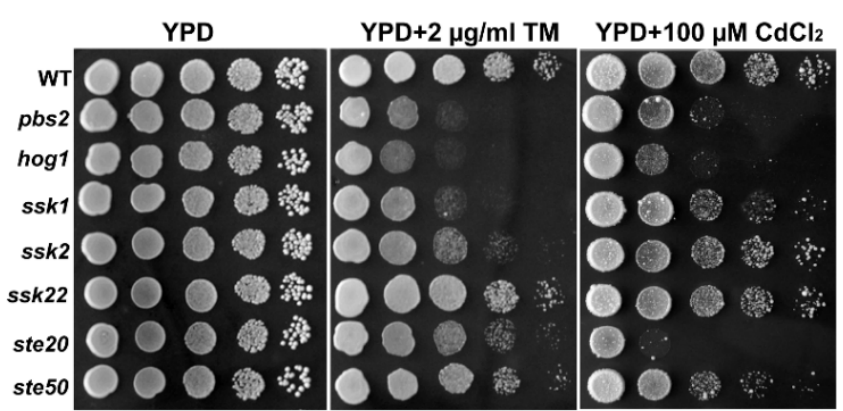

B

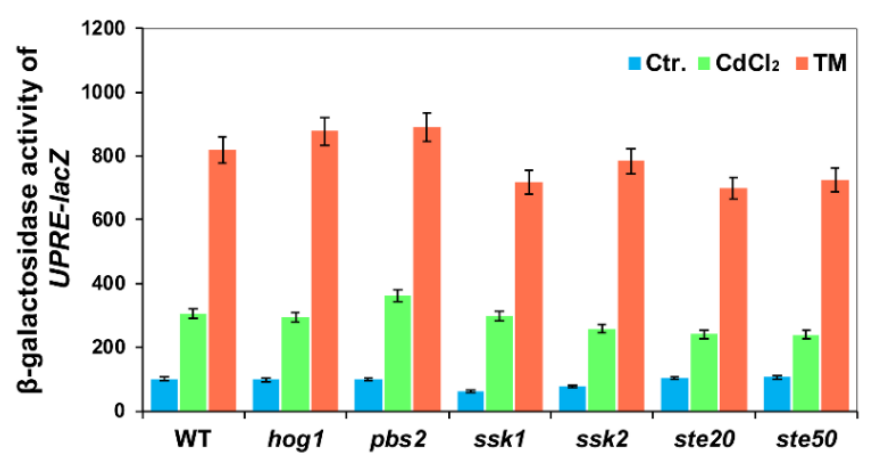

C

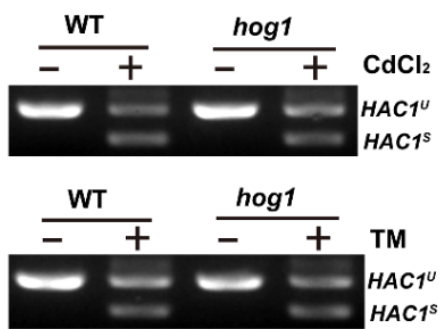

D

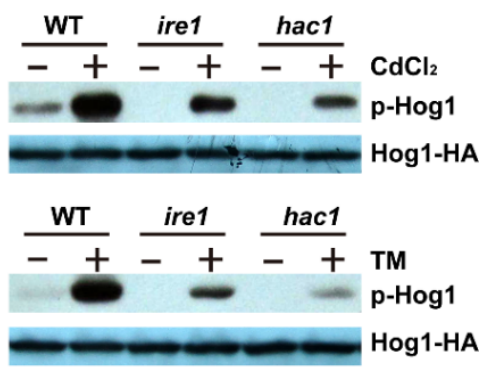

Figure 1. Hog1 is required for the cell growth in cadmium and Tm stresses and its activation is dependent on the UPR pathway. (A) Phenotypes of the mutants in the HOG pathway cadmium and Tm stress. Cells were grown overnight at $30{ }^{\circ} \mathrm{C}$ in liquid YPD and serially diluted 10-fold, then they were spotted on the indicated plates and incubated for 2-3 days at $30{ }^{\circ} \mathrm{C}$. (B) $\beta$-galactosidase activities of UPRE-lacZ in wild-type BY4741 and the mutants in the HOG pathway in cadmium or Tm response. All experiments were performed in triplicate, and the error bars represent mean \pm standard deviation. (C) HAC1 splicing was determined by RT-PCR analysis in the wild-type and hog $1 \Delta$ strains treated with $50 \mu \mathrm{M} \mathrm{CdCl}_{2}$ or $1 \mu \mathrm{g} / \mathrm{mL}$ Tm for $1 \mathrm{~h}$, respectively. (D) Phosphorylation of Hog1-HA in wild-type BY4741, hac1 $\Delta$ and ire $1 \Delta$ strains in response to cadmium and Tm. Cells of BY4741, hac1 $\Delta$ and ire $1 \Delta$ expressing Hog1-HA were grown at $30^{\circ} \mathrm{C}$ in liquid YPD to log-phase and then treated with $50 \mu \mathrm{M} \mathrm{CdCl}_{2}$ or $1 \mu \mathrm{g} / \mathrm{mL}$ Tm for $1 \mathrm{~h}$. Cells were then collected for protein extraction and Western blot analysis with phospho-p38 MAPK antibody or the anti-HA antibodies, respectively.

Next, we tested the unfolded protein response in mutants of the HOG pathway by measuring the $\beta$-galactosidase activity expressed by UPRE-lac $Z$ reporter. We showed that neither the deletion of HOG1 nor PBS2 influenced the expression of UPRE-lacZ in response to Cd or TM compared with that of WT cells (Figure 1B), consistent with a previous observation that the HOG pathway controls TM-induced ER stress independent of the UPR pathway [38]. In addition, we also investigated whether the splicing level of HAC1 mRNA was affected by the HOG pathway. In hog1 $1 \Delta$ mutants, HAC1 mRNA could be spliced normally as that of WT cells in response to Cd or TM stress (Figure 1C). In contrast, we showed that Hog1 phosphorylation levels were significantly increased in WT cells following Cd or TM treatment, but reduced in the absence of Ire1 and Hac1 (Figure 1D), consistent with the results of DTT and TM treatments [30]. Taken together, these results indicate that the components of the HOG pathway are essential for Cd tolerance and the Ire1 and Hac1-mediated UPR pathway contributes to the phosphorylation activation of 
the MAPK Hog1 in response to Cd, although the HOG pathway is not required for the activation of UPR in response to cadmium.

\subsection{Ire1 and Hac1 Regulate the Nuclear Localisation of Hog1}

Since the nuclear localisation of Hog1 is regulated by its phosphorylation level $[39,40]$, and since Ire1 and Hac1 regulate the phosphorylated activation of Hog1 from the above results, we tried to evaluate whether subcellular localisation of Hog1 is regulated by Ire1 and Hac1 in response to TM or Cd. To achieve this, we tagged Hog1 with GFP at its C-terminus in the WT BY4741, ire1 $\Delta$ and hac1 $\Delta$ mutant strains. As expected, Hog1-GPF fusion protein displayed a significant nuclear relocation in the presence of $0.4 \mathrm{M} \mathrm{NaCl}$ in WT cells within 5 min (Figure 2), which was consistent with the previous study [41]. Upon ER stress, Hog1-GFP also displayed a nuclear location, as previously reported after $1 \mathrm{~h}$ of TM treatment [30]. However, upon Cd exposure, Hog1-GFP displayed similar cytoplasmic localisation to that observed in untreated cells after $1 \mathrm{~h}$ of $\mathrm{Cd}$ treatment, which was in contrast to the situation under osmotic stress conditions (Figure 2). Surprisingly, the levels of Hog1-GFP fusion protein accumulated in the nuclei of hac $1 \Delta$ and ire $1 \Delta$ mutants were much higher than in the WT cells, although there were no significant differences with or without TM or Cd treatment (Figure 2). It is worth noting that Hog1-GFP was transported to the cytosol after a 30 min treatment with $0.4 \mathrm{M} \mathrm{NaCl}$ in WT cells, while it could still accumulate in the nuclei of ire1 $\Delta$ and hac1 $\Delta$ mutants. The nuclear accumulation of Hog1 is based on its phosphorylation level, and Hog1 is phosphorylated upon ER stress and this is dependent on the UPR pathway [30]. However, disruption of the UPR pathway could still promote nuclear accumulation. These results indicate that much more phosphorylated Hog1 must enter the nucleus, where it functions in an unknown way, when the Ire1-mediated UPR pathway is inhibited.

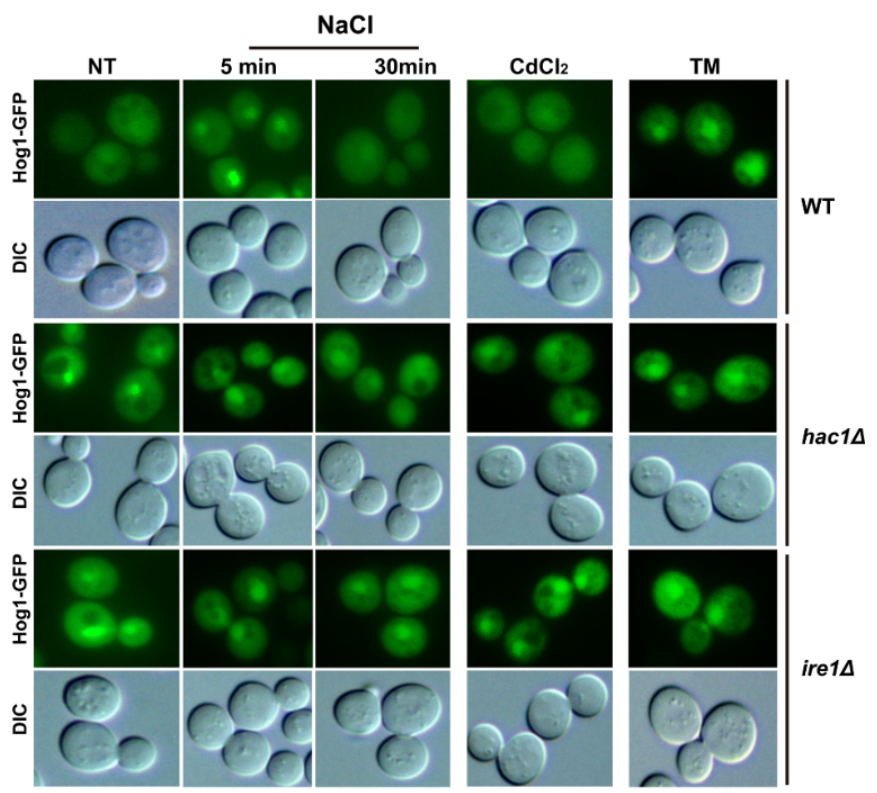

Figure 2. Ire1 and Hac1 regulate the nucleus localization of Hog1. Subcellular localization of Hog1-GFP in BY4741, hac1 $\Delta$ and ire1 $\Delta$ strains. Log-phase growing cells of BY4741, hac1 $\Delta$ and ire $1 \Delta$ expressing C-terminally GFP-tagged Hog1 were treated with $0.4 \mathrm{M} \mathrm{NaCl}, 50 \mu \mathrm{M} \mathrm{CdCl}_{2}$ or $1 \mu \mathrm{g} / \mathrm{mL}$ TM respectively. Cells were visualised under a Nikon ECLIPSE 80i fluorescent microscope.

\subsection{The MAPK Slt2 Is Required for Both Cadmium- and Tm-Induced UPR Pathways}

Among the five upstream receptors of Wsc1, Wsc2, Wsc3, Mid2 and Mtl1, we found that $\operatorname{wsc} 1 \Delta$ mutant showed a significant growth defect in response to TM, while mid $2 \Delta$ mutant showed a Cd-sensitive phenotype (Figure $3 \mathrm{~A}$ ). These results are consistent with those of previous studies [35], and also indicate that there may be different roles for the 
CWI pathway in Cd- and TM-induced ER stress. Since cell wall stress activates Slt2 via both Wsc1 and Mid2 sensors [42], both TM- and Cd-induced stresses are distinct from cell wall stress. Three transcription factors, Rlm1, Swi4 and Swi6, are known to be regulated by Slt2 [43,44]. Rlm1 is one of the known targets of Slt2, and Slt2 can be positively regulated by R $\operatorname{lm} 1$ [45]. As shown in Figure 3A, we found that only the $r \operatorname{lm} 1$ mutant displayed a growth defect on TM plates (Figure 3A), while swit and swi6 mutants were only sensitive to Cd stress.

\section{A}

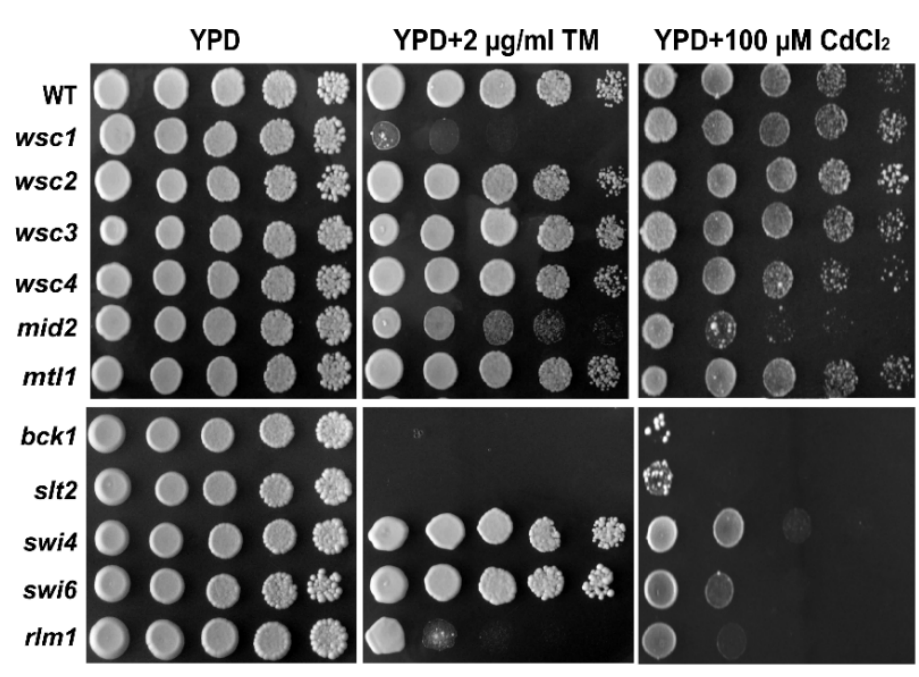

B

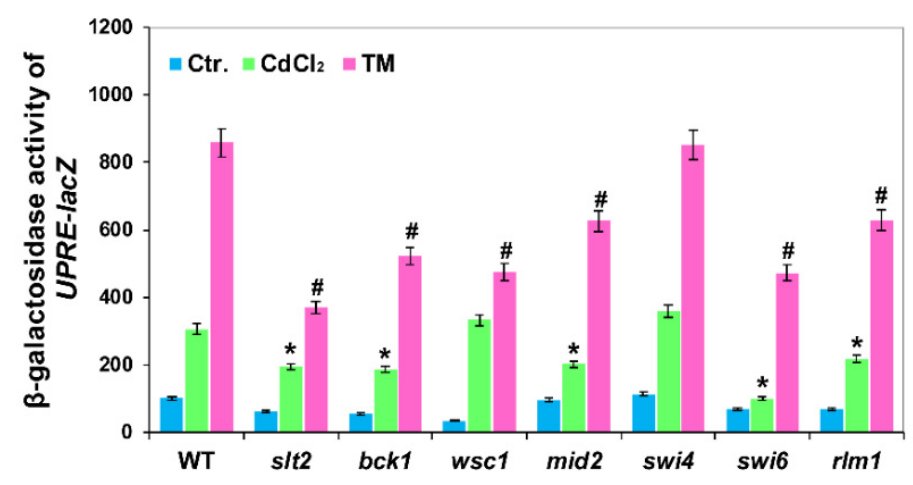

C

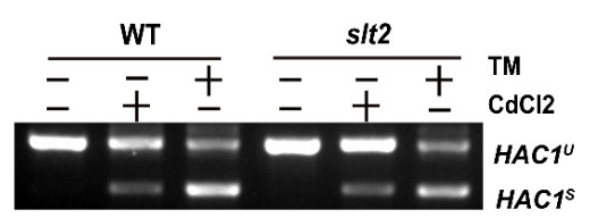

Figure 3. Slt2 is required for the activation of the UPR pathway. (A) Phenotypes of the mutants in the CMI pathway upon cadmium and TM stress. Cells were grown overnight at $30^{\circ} \mathrm{C}$ in liquid YPD and serially diluted 10-fold, then they were spotted on the indicated plates and incubated for 2-3 days at $30{ }^{\circ} \mathrm{C}$. (B) $\beta$-galactosidase activities of UPRE-lacZ in wild-type BY4741 and the mutants in the CWI pathway in cadmium or TM response. All of the experiments were performed in triplicate, and the error bars represent mean \pm standard deviation. Results were analysed using paired-samples $t$-test function of SPSS 19.0. The significant difference of $p<0.01$ is showed as "*" or "\#" when cells were treated with cadmium or TM, respectively. (C) HAC1 splicing was determined by RT-PCR analysis in the wild-type and slt $2 \Delta$ strains treated with $50 \mu \mathrm{M} \mathrm{CdCl}_{2}$ or $1 \mu \mathrm{g} / \mathrm{mL} \mathrm{Tm}$ for $1 \mathrm{~h}$, respectively.

Next, we examined the activity of UPRE-lacZ in the mutants of CWI pathway in cadmium stress. The deletion of SLT2 and its upstream component of BCK1 resulted in impaired expression of UPRE-lacZ during TM and Cd stress (Figure 3B). Interestingly, as shown in Figure 3B, the UPRE-lacZ activity was reduced in both swi6 $\Delta$ and $r \operatorname{lm} 1 \Delta$ mutants 
in response to $\mathrm{Cd}$ and TM stress. However, an additional observation indicated that HAC1 mRNA splicing was not affected by deletion of SLT2 in response to Cd (Figure 3C), in agreement with the response to ER stress reported previously [23]. These results indicate that Slt2 can regulate UPR, and this is dependent on Swi6 and Rlm1 transcription factors but independent of Ire1 or Hac1 during Cd- and TM-induced ER stress.

\subsection{Phosphorylation and Expression of Slt2 Is Independent of the Ire1-Mediated UPR Pathway}

Previous work showed that the phosphorylation level of Slt2 is increased by Cd through the cell surface sensor Mid2 [25], while phosphorylation of Slt2 is regulated by the Wsc1 senor following TM treatment [35]. To investigate whether UPR pathway regulated the phosphorylation of Slt2, we analysed the phosphorylation of Slt2 in hac1 $\Delta$ and ire1 $\Delta$ mutants. We showed that the phosphorylation level of Slt2 was not influenced in the absence of Ire1 or Hac1 in response to Cd, consistent with the results of TM treatment (Figure 4A) [35]. These results indicate that phosphorylation of Slt2 following both TM and $\mathrm{Cd}$ treatment was independent of the UPR pathway.

\section{A}

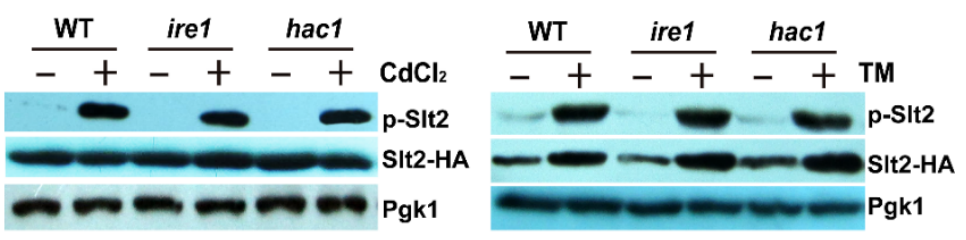

B

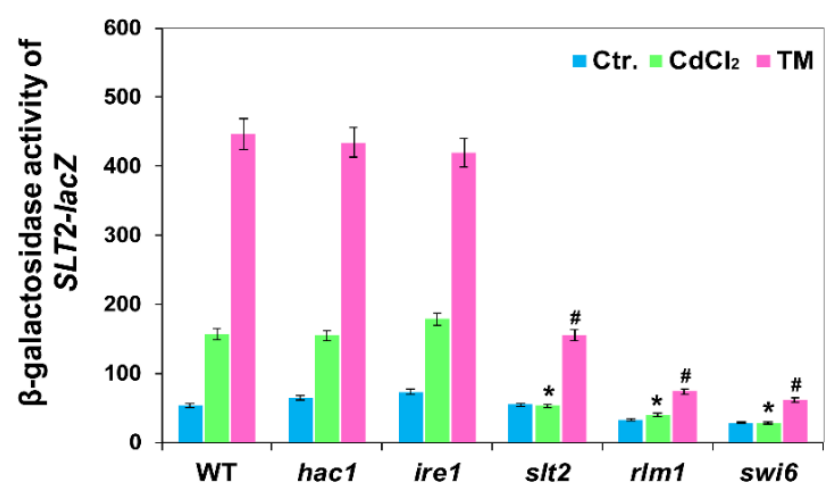

Figure 4. Phosphorylation and expression of Slt2 is independent of the Ire1-mediated UPR pathway. (A) Phosphorylation of Slt2-HA in wild-type BY4741, hac1 $\Delta$ and ire1 $\Delta$ strains in response to cadmium and TM. Cells of BY4741, hac1 $\Delta$ and ire $1 \Delta$ expressing Slt2-HA were grown at $30{ }^{\circ} \mathrm{C}$ in liquid YPD to log-phase and then treated with $50 \mu \mathrm{M} \mathrm{CdCl}_{2}$ or $1 \mu \mathrm{g} / \mathrm{mL}$ TM for $1 \mathrm{~h}$. Cells were then collected for protein extraction and Western blot analysis with phospho-p44/42 MAPK antibody or the anti-HA antibodies, respectively. (B) $\beta$-galactosidase activities of SLT2-lacZ in response to cadmium or Tm. All of the experiments were performed in triplicate, and the error bars represent mean \pm standard deviation. Results were analysed using paired-samples $t$-test function of SPSS 19.0. The significant difference of $p<0.01$ is showed as "*" or "\#" when cells were treated with cadmium or TM, respectively.

Since the expression of SLT2 can be induced by ER stress [23], to investigate whether the expression of $S L T 2$ was regulated by Hac1 and Ire1 in response to $C d$, we next monitored the expression of SLT2-lacZ in the WT BY4741, hac1 $\Delta$, ire $1 \Delta$, swi4 $\Delta$, swi6 $\Delta$ and $r \operatorname{lm} 1 \Delta$ strains. We found that SLT2-lacZ could be induced by Cd and TM stress in WT cells and the expression of Slt2-lac $Z$ displayed the same response in hac $1 \Delta$ and ire $1 \Delta$ cells as WT cells in response to $\mathrm{Cd}$ and TM stress (Figure 4B) [12]. It should be noted that the induction of Slt2lacZ was inhibited in both $\operatorname{rlm} 1 \Delta$ and swi6 $\Delta$ mutants upon Cd and TM stress (Figure 4B), indicating that the transcription factor Swi6 also regulates SLT2 expression in addition to Rlm1. Collectively, these results suggest that the expression of SLT2 is significantly 
induced by Cd and TM, and this is dependent on the transcription factor Swi6 and Rlm1, but independent of the UPR signalling pathway.

\subsection{Defection of UPR Pathway Promotes Slt2 to Localise in Cytosol and Bud Neck}

Since the phosphorylation of Slt2 can be activated by ER stress, and since Slt2 is required for cell growth and the activation of UPR in response to ER stress, we wondered whether the localisation of Slt2 is also regulated by ER stress. Therefore, we measured the localisation of Slt2 using GFP-tagged Slt2-GFP fusion protein in WT BY4741, ire1 $\Delta$ and hac1 $\Delta$ strains after treatment with $\mathrm{Cd}$ and TM. As shown in Figure 5, the nuclear localisation of Slt2 was not affected in wide type BY4741 cells in response to TM or Cd. Surprisingly, we found that in the hac1 $\Delta$ and ire1 $\Delta$ mutants, Slt2-GFP could be visualised in the nucleus, the cytosol, and especially the bud neck, and the distribution was similar in non-treated and stressed cells. Upon ER stress, the MAP kinase Slt2 plays crucial roles in regulating the localisation and morphology of the septin ring via a mechanism independent of the UPR pathway mediated by the ER transmembrane receptor riboendonuclease Ire1 [35]. Since Slt2 can regulate septin structures, cER inheritance, and cytokinesis upon ER stress, which is independent of the Ire1-mediated UPR [35], the deletion of Ire1 or Hac1 might result in a greater need for Slt2 function to regulate these processes, which has not been observed in WT cells. From this point of view, we reasoned that when Ire1 or Hac1 is absent, the MAP kinase Slt2 must be transported to the bud neck to perform some of these other unknown functions.

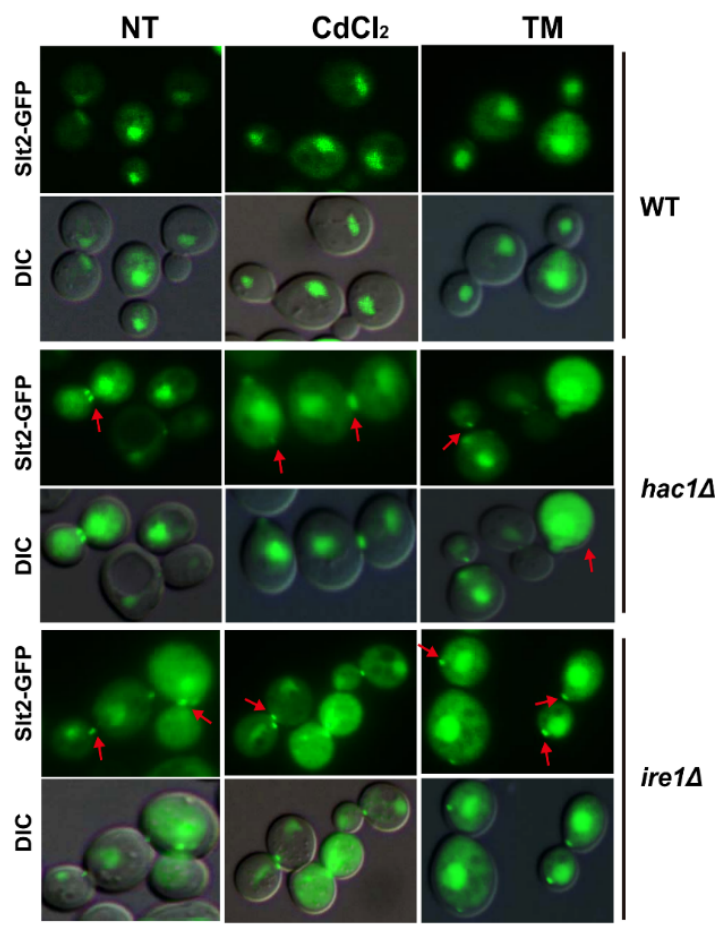

Figure 5. Subcellular localization of Slt2-GFP in BY4741, hac1 $\Delta$ and ire1 $\Delta$ strains. Log-phase growing cells of BY4741, hac1 $\Delta$ and ire1 $\Delta$ expressing C-terminally GFP-tagged Slt2 were treated with $50 \mu \mathrm{M} \mathrm{CdCl}_{2}$ or $1 \mu \mathrm{g} / \mathrm{mL}$ TM, respectively. Cells were visualised under a Nikon ECLIPSE 80i fluorescent microscope.

2.6. UPR, HOG and CWI Pathways Are All Required for Cadmium- and Tm-Induced ROS and Cell Death

Cadmium-induced ROS plays a significant role in cell death [8]. Cd can induce cell death in human T cells, mouse thymocytes, kidney cell lines, smooth muscle cells (A7r5), mouse liver cells and others [46]. In addition, the two MAPKs of Hog1 and Slt2 are also required for yeast mitophagy [47]. Since cadmium can generate intracellular ROS, to investigate whether UPR, HOG or CWI pathways was involved in the cadmium-induced 
ROS and cell death, we analysed ROS and cell death, we measured the intracellular ROS levels and cell death in the related mutants of UPR, HOG and CWI pathways. Herein, we showed that the levels of ROS and cell death were both induced in WT, hac1 $\Delta$, ire $1 \Delta$, hog $1 \Delta$, pbs $2 \Delta$, slt $2 \Delta$ and $b c k 1 \Delta$ cells in response to Cd or TM, and TM-induced ROS and cell death levels were higher than Cd-induced levels (Figure 6). In particular, intracellular ROS and cell death levels for the above mutant cells were all higher than those of WT cells when treated with $\mathrm{Cd}$ or TM, and even under the untreated control conditions. These findings suggest that Ire1-mediated ER stress, and the two MAPK pathways of HOG and CWI are all required for the induction of ROS and cell death in response to cadmium and TM. In addition, ROS and cell death levels in slt2 and $b c k 1$ mutants were significantly higher than in hog1 and pbs2 mutants in response to cadmium, Tm and even in the untreated cells (Figure 6), indicating that CWI pathway might play more important roles in regulating ROS levels and cell death.

A

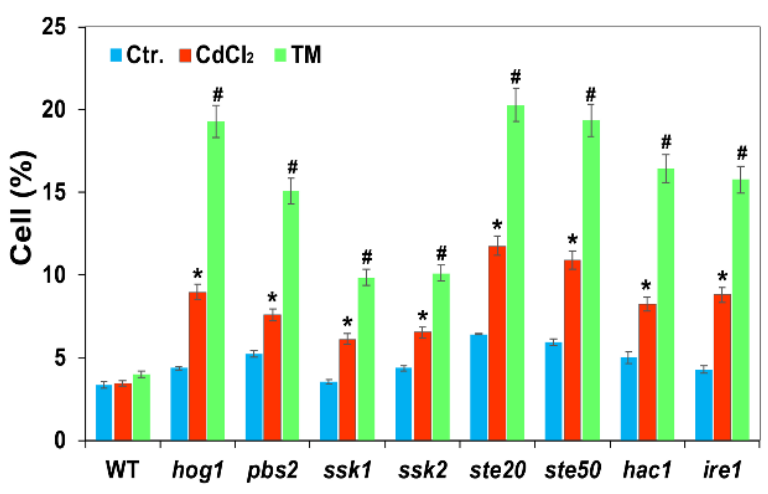

C

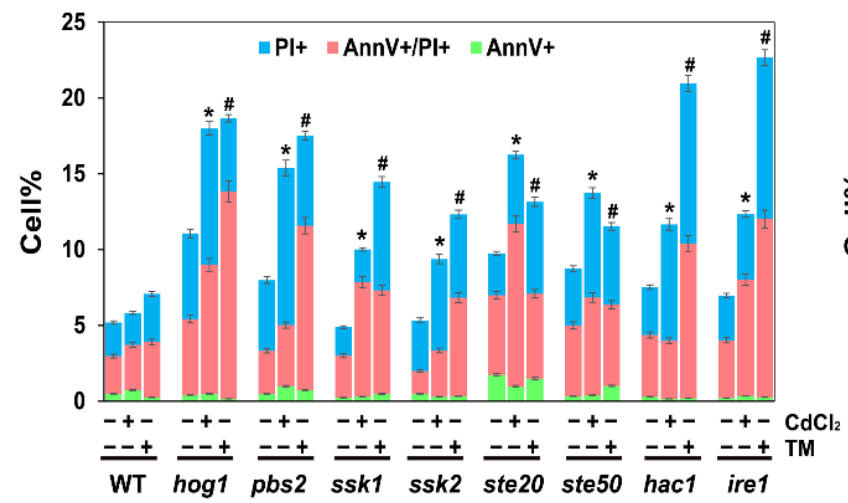

B

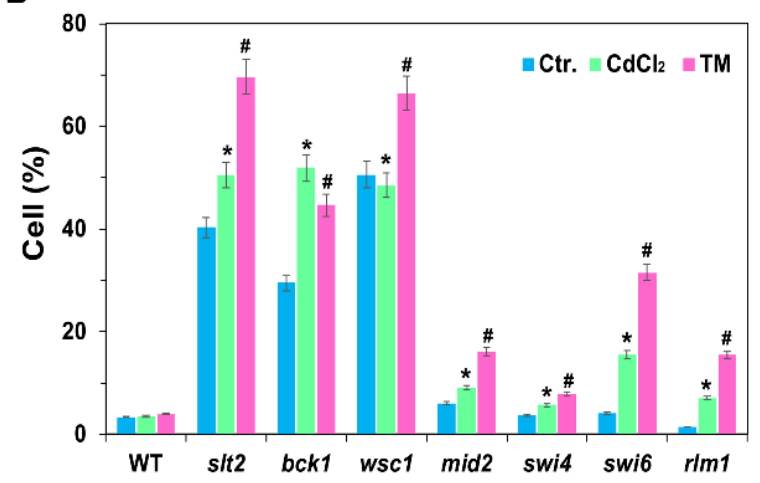

D

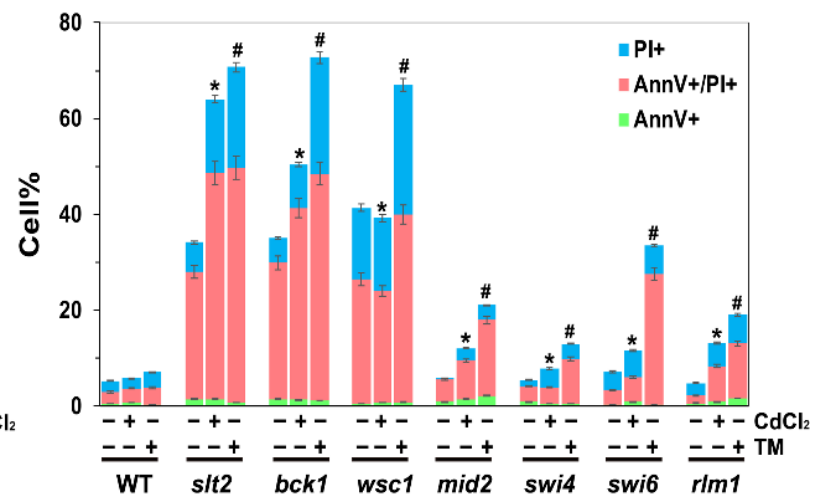

Figure 6. Hog1 and Slt2 are both required for the cadmium-induced and TM-induced ROS and cell death. (A) Intracellular ROS assay in the HOG pathway mutants. (B) Intracellular ROS assay in the CWI pathway mutants. (C) Cell death assay in the HOG pathway mutants. (D) Cell death assay in the CWI pathway mutants. The indicated cells were first grown to middle $\log$ phase and then were treated with $50 \mu \mathrm{M} \mathrm{CdCl}_{2}$ or $1 \mu \mathrm{g} / \mathrm{mL}$ tunicamycin for an additional $4 \mathrm{~h}$. The intracellular ROS levels were tested using dihydroethidium (DHE), while cell death was measured with an Annexin V staining kit. All of the samples were visualised by fluorescence microscopy. At least 500 cells were counted in each sample, and data were presented as the mean standard deviation (SD) from three independent samples. Results were analysed using paired-samples $t$-test function of SPSS 19.0. The significant difference of $p<0.01$ is showed as "** or "\#" when cells were treated with cadmium or Tm, respectively.

\section{Discussion}

The two MAPK pathways play crucial roles in resistance to various stress. For instance, HOG pathway participates in hyper-osmotic stress response and the ER stress response [30,48], while the CWI pathway is involved in cell wall integrity stress, ER stress, hypo-osmotic stress response, and inheritance regulation [35-37]. In this report, we have shown that the HOG and CWI pathways play significant roles in the cadmium-induced 
toxicity. We propose that the activation of the MAP kinase Hog1 in response to Cd and TM stress is partly dependent on the Ire1-mediated UPR response, while the Cd- and TM-mediated activation of the MAP kinase Slt2 is completely independent of the UPR response. We also showed that the splicing of $\mathrm{mHAC} 1$ is neither dependent on Hog1 nor Slt2. Moreover, Slt2 kinase, but not Hog1 kinase, is required for the induction of the UPR in response to cadmium, which was similar to the induction of TM-induced UPR signalling as described previously [22]. In addition, in response to ER stress, the MAPK Hog1 is phosphorylated and helps the ER regain homeostasis through promoting HAC1 mRNA splicing [30]. Herein, we confirmed that Slt2 was also involved in UPR recovery along with Hog1 kinase based on measuring HAC1 mRNA splicing levels in WT, hog1 $\triangle$ and slt2 $\Delta$ strains (Figure S1).

In humans and other mammals, the kidney and liver are considered as two major target organs for cadmium-induced toxicity [49]. The oxidative stress induced by cadmium can damage mitochondria and, thus, disturb the respiratory activity and cause a series of cell injuries, which then induce apoptosis or necrosis and lead to renal dysfunction or even cell death [50]. On the other hand, cadmium also triggers renal injury through causing ER stress which can induce apoptosis in response to cadmium stress [51]. Since the phosphorylation of two mammalian MAPK family members, including the extracellular signal-regulated kinase (ERK)-1/2 and p38 MAPK, can be induced by cadmium, and since the cadmium-induced phosphorylation of yeast p38 MAPK Hog1 is partially dependent on the UPR pathway, we speculate that ERK and p38 MAPK might also be correlated with the UPR pathway in the cadmium-induced toxicity in the kidney.

It has been reported previously that the Wsc1 sensor is required for cell growth, activation of the UPR, and phosphorylation of Slt2 in response to TM stress [35], while the Mid2 sensor is required for activation of the CFW-induced UPR response and cell survival in response to CFW [36]. We showed that the transcription factor $\operatorname{Slm} 1$ is required for Tm-induced UPR process, while Swi6 is required for the CWI-induced UPR process. In the present study, we showed that Cd-induced UPR response is also mediated by Mid2, and both Swi6 and Slm1 are required for UPRE-lacZ expression. These results indicate that although Cd shares some of the same characteristics with TM- and CFW-induced UPR, it also has some unique characteristics.

The MAP kinases Hog1 and Slt 2 usually accumulate in the nucleus, where they activate some target transcription factors in response to stimuli, but they may have cytoplasmic substrates and function in the cytoplasm. It has been reported that Slt2 and Hog1 remain in the cytoplasm, although they are both phosphorylated during mitophagy [47]. Upon osmotic stress, Hog1 is activated by Pbs2 through two pathways, one mediated by the Sho1 branch and the other mediated by the Ssk1 branch [52]. Activated Hog1 can be imported into the nucleus to regulate some transporters that activate some target genes to help cells adapt to stress $[39,40]$. When the stress is eliminated, dephosphorylated Hog1 returns back to the cytoplasm [53]. Interestingly, we showed that dephosphorylated or sparsely phosphorylated Hog1 could stay in the nucleus in both ire1 and hac1 mutants, even when there was no stress. This suggests that Ire1 and Hac1 play important roles in importing Hog1 from the nucleus to the cytoplasm, and the dephosphorylated or low phosphorylated Hog1 might perform some unknown roles in the nucleus. Slt2 localises mainly in the nucleus, however, a polarised localisation of Slt2 at bud tips might also play significant roles. For instance, it has been reported that blocking the bud tip localisation of Slt2 via Slt2 mutation of Slt2-LA can suppress the ER inheritance defect of $p t c 1 \Delta$ mutant cells [54]. ER stress impacts the cell cycle by altering spectin stabilisation, blocking cytokinesis, and delaying ER inheritance, all of which are independent of the Ire1-mediated UPR pathway, but dependent on the MAP kinase Slt2 [35]. Herein, we demonstrated that Slt2-GFP fusion protein showed both nucleus and bud tip localisation in ire1 and hac1 mutants. From this perspective, Ire1 and Hac1 might also be involved in maintaining ER inheritance, cytokinesis, and septin structure along with the MAP kinase Slt2, although they might be not essential for these processes. 
Our studies are important to understand the cadmium-induced toxicity. In budding yeast, cadmium can activate the UPR pathway, as well as the protein kinases of Hog1 and St12, which are all essential for preventing cells from cell death caused by cadmium. The UPR pathway is required for the phosphorylated activation of Hog1 but not Slt2 in response to cadmium stress. Even so, Slt2 could regulate UPRE-lacZ expression through two transcription factors of Swi6 and RIm1. Therefore, we speculate that, in response to cadmium toxicity, the UPR pathway performs its role of inhibiting cell death partially through activating Hog1, while Slt2 performs its role partially through activating the UPR pathway. IRE1 or HAC1 deletion severely inhibited the activation of the UPR pathway, and also reduced the phosphorylation level of Hog1. In this case, in order to reduce the damage to cells caused by the lack of UPR pathway, more activated Hog1 must be kept in the nucleus and more activated Slt2 might be needed to transport to the cytosol or the bud neck, to perform some crucial functions.

\section{Materials and Methods}

\subsection{Yeast Strains and Growth Media}

All S. cerevisiae strains used in this study are listed in Table 1. For nonselective conditions, yeast cells were grown in YPD medium, which was prepared by mixing $2 \%$ $(w / v)$ glucose, $2 \%(w / v)$ tryptone and $1 \%(w / v)$ yeast extract. For the selection and maintenance of plasmids, an SC (synthetic complete) medium $(0.17 \%(w / v)$ yeast nitrogen base, $2 \%(w / v)$ glucose, $0.5 \%$ ammonia sulfate) lacking appropriate nutrients was used. Solid media were prepared by adding $2 \%(w / v)$ agar to YPD or SC media when necessary. All yeast strains were cultured at $30^{\circ} \mathrm{C}$. Cadmium chloride and DTT were purchased from Sangon Biotech (Shanghai, China). TM and Dihydroethidium were purchased from Sigma (Beijing, China). Annexin V was purchased from Solarbio (Beijing, China).

Table 1. S. cerevisiae strains used in this study.

\begin{tabular}{|c|c|c|}
\hline Name & Relevant Genotype & Source/Reference \\
\hline BY4741 & MATa his $3 \Delta 1$ leu $2 \Delta 0$ met $15 \Delta 0$ ura $3 \Delta 0$ & [55] \\
\hline$p b s 2 \Delta$ & BY4741 pbs2::kanMX4 & [55] \\
\hline hog $1 \Delta$ & BY4741 hog1::kanMX4 & [55] \\
\hline $\operatorname{ssk} 1 \Delta$ & BY4741 ssk1::kanMX4 & [55] \\
\hline ssk2 $\Delta$ & BY4741 ssk2::kanMX4 & [55] \\
\hline$s s k 22 \Delta$ & BY4741 ssk22::kanMX4 & [55] \\
\hline ste $20 \Delta$ & BY4741 ste $20:: k a n M X 4$ & [55] \\
\hline ste $50 \Delta$ & BY4741 ste50::kanMX4 & [55] \\
\hline $\operatorname{ire} 1 \Delta$ & BY4741 ire1::kanMX4 & [55] \\
\hline hac1s & BY4741 hac1::kanMX4 & [55] \\
\hline $\operatorname{wsc} 1 \Delta$ & BY4741 wsc1::kanMX4 & [55] \\
\hline $\csc 2 \Delta$ & BY4741 wsc2::kanMX4 & [55] \\
\hline$w s c 3 \Delta$ & BY4741 wsc3::kanMX4 & [55] \\
\hline$w s c 4 \Delta$ & BY4741 wsc4::kanMX4 & [55] \\
\hline $\operatorname{mid} 2 \Delta$ & BY4741 mid2::kanMX4 & [55] \\
\hline$m t l 1 \Delta$ & BY4741 mtl1::kanMX4 & [55] \\
\hline$b c k 1 \Delta$ & BY4741 bck1::kanMX4 & [55] \\
\hline slt2 $\Delta$ & BY4741 slt2::kanMX4 & [55] \\
\hline swi4 $\Delta$ & BY4741 swi4::kanMX4 & [55] \\
\hline swi6 $\Delta$ & BY4741 swi6::kanMX4 & [55] \\
\hline$r \operatorname{lm} 1 \Delta$ & BY4741 rlm1::kanMX4 & [55] \\
\hline BY4741 HOG1-HA & BY4741 HOG1-HA-HIS3MX6 & This study \\
\hline ire1 $\Delta$ HOG1-HA & BY4741 ire1::kanMX4 HOG1-HA-HIS3MX6 & This study \\
\hline hac1 $\Delta$ HOG1-HA & BY4741 hac1::kanMX4 HOG1-HA-HIS3MX6 & This study \\
\hline BY4741 HOG1-GFP & BY4741 HOG1-GFP-HIS3MX6 & This study \\
\hline ire1 $\triangle$ HOG1-GFP & BY4741 ire1::kanMX4 HOG1-GFP-HIS3MX6 & This study \\
\hline hac1 $\triangle$ HOG1-GFP & BY4741 hac1::kanMX4 HOG1-GFP-HIS3MX6 & This study \\
\hline
\end{tabular}


Table 1. Cont.

\begin{tabular}{ccc}
\hline Name & Relevant Genotype & Source/Reference \\
\hline BY4741 SLT2-HA & BY4741 SLT2-HA-HIS3MX6 & This study \\
ire1 $\Delta$ SLT2-HA & BY4741 ire1::kanMX4 SLT2-HA-HIS3MX6 & This study \\
hac1 $\Delta$ SLT2-HA & BY4741 hac1::kanMX4 SLT2-HA-HIS3MX6 & This study \\
BY4741 SLT2-GFP & BY4741 SLT2-GFP-HIS3MX6 & This study \\
ire1 $\Delta$ SLT2-GFP & BY4741 ire1::kanMX4 SLT2-GFP-HIS3MX6 & This study \\
hac1 SLT2-GFP & BY4741 hac1::kanMX4 SLT2-GFP-HIS3MX6 & This study \\
\hline
\end{tabular}

\subsection{Phenotype Assay}

To investigate the grown differences of mutant cells in response to cadmium and $\mathrm{TM}$, the serial dilution assay method was performed as described previously [56]. Before analysis, mutant cells were first cultured overnight in liquid YPD medium, and then cells were dotted onto YPD, YPD plus $100 \mu \mathrm{M} \mathrm{CdCl}_{2}$, or YPD plus $2 \mu \mathrm{g} / \mathrm{mL}$ TM after the 10 -fold serially dilution with $\mathrm{ddH}_{2} \mathrm{O}$. All cells were cultured at $30^{\circ} \mathrm{C}$ for 2 to 3 days.

\subsection{DNA Manipulations}

To construct the Hog1-HA and Slt2-HA fusion proteins, we amplified the 3HAHIS3MX6 cassettes from the pFA6a-3HA-HIS3MX6 plasmid [57] with primer pairs, Hog1$\mathrm{CF} / \mathrm{Hog} 1-\mathrm{CR}$ or Slt2-CF/Stl2-CR, which were then transformed into BY4741 (wild type, $\mathrm{WT}$ ), hac1 $1 \Delta$, and ire $1 \Delta$ strains and integrated into the $3^{\prime}$ end of HOG1 or SLT2, respectively. The correct transformants expressing Hog1-HA or Slt2-HA fusion protein were confirmed by PCR with primers Hog1-check-F/Hog1-check-R and Slt2-check-F/Slt2-check-R, respectively. To construct the SLT2-lacZ reporter, we first amplified the promoter of SLT2 with primers SLT2-LF/SLT2-LR and replaced it with the PMR1 promoter in pRS316-PMR1lacZ [56], yielding pRS316-SLT2-lacZ.

To investigate the localisation of Hog1 and Slt2, Hog1-GFP and Slt2-GFP fusion proteins were constructed in the WT BY4741, ire $1 \Delta$, and hac1 $\Delta$ mutant strains, respectively. To achieve this, the GFP-HIS3MX6 cassette was first amplified with primers HOG1-CGFP-F/HOG1-CGFP-R or SLT2-CGFP-F/SLT2-CGFP-R from plasmid pFA6aGFP-HIS3MX6 [57], respectively, and integrated into the WT BY4741, ire1 $\Delta$, and hac1 $\Delta$ mutant strains. Correct integration was confirmed by PCR with primers Hog1-check$\mathrm{F} /$ Hog1-check-R and Slt2-check-F/Slt2-check-R, respectively. The primers were all listed in Table S1.

\subsection{Microscopy Assay}

C-terminally GFP-tagged Hog1-GFP and Slt2-GFP were used to visualise Hog1 or Slt2 localisation, respectively. Log phase cells expressing Hog1-GFP fusion protein were first treated with or without $0.4 \mathrm{M} \mathrm{NaCl}$ for 5 or $30 \mathrm{~min}, 50 \mu \mathrm{M} \mathrm{CdCl}_{2}$ and $1 \mu \mathrm{g} / \mathrm{mL} \mathrm{TM}$ for $1 \mathrm{~h}$, respectively. To analyse the subcellular localisation of Slt2-GFP fusion protein, log phase cells expressing Slt2-GFP were first treated with $50 \mu \mathrm{M} \mathrm{CdCl}_{2}$ or $1 \mu \mathrm{g} / \mathrm{mL} \mathrm{TM}$ for $2 \mathrm{~h}$, respectively. All cells were visualised using a Nikon Eclipse 80i epifluorescence microscope.

\subsection{Intracellular ROS and Cell Death Assay}

Yeast cells were first cultured overnight in YPD medium, then inoculated into fresh $\mathrm{SC}$ medium to an initial $\mathrm{OD}_{600}$ of $\sim 0.1$. When cells had grown to middle log phase, they were split into three aliquots, and cultured in the absence or presence of $50 \mu \mathrm{M} \mathrm{CdCl}_{2}$ or $1 \mu \mathrm{g} / \mathrm{mL}$ TM for an additional $4 \mathrm{~h}$. Next, $5 \times 10^{6}$ cells were harvested by centrifugation and used to analyse the intracellular ROS levels and cell death. To measure the intracellular ROS levels, cells were first resuspended in $250 \mu \mathrm{L}$ of phosphate-buffered saline (PBS) with $2.5 \mu \mathrm{g} / \mathrm{mL}$ dihydroethidium (DHE, sigma, Beijing, China) and incubated in the dark for $30 \mathrm{~min}$. Annexin V (Solarbio, Beijing, China) staining analysis was used to test the cell death rates in response to $\mathrm{Cd}$ and performed as previously described [58]. All samples were visualised by fluorescence microscopy using a Nikon Eclipse 80i epifluorescence 
microscope and positive cells were counted by Image J software. At least 500 cells were counted in each sample, and the data are presented as the mean \pm standard deviation (SD) from three independent samples.

\section{6. $\beta$-Galactosidase Activity Assay}

To measure the UPRE-driven $\beta$-galactosidase activity, pMCZ-Y plasmid [59] was transformed into the wild type BY4741 and the related mutant cells. Transformants were first cultured overnight in SD-URA medium, then inoculated into three aliquots of fresh SC medium and grown to middle log phase, after which $50 \mu \mathrm{MCdCl}_{2}$ or $1 \mu \mathrm{g} / \mathrm{mL} \mathrm{TM}$ was added to the medium and cells were cultured for an additional $2 \mathrm{~h}$ when necessary. Yeast cells were harvested by centrifugation to extract total proteins and $\beta$-galactosidase activity was measured as described previously [56]. Data are presented as mean \pm SD from six independent experiments.

\subsection{RNA Extraction and RT-PCR Analysis}

For RNA preparation, the indicated yeast cells were first treated with or without $50 \mu \mathrm{M}$ $\mathrm{CdCl}_{2}$ or $1 \mu \mathrm{g} / \mathrm{mL} \mathrm{TM}$ for $2 \mathrm{~h}$. In the UPR recovery experiment, TM-treated BY4741, hog $1 \Delta$ and slt $2 \Delta$ cells were first washed once with fresh SC medium and then were incubated in fresh SC medium for an additional $6 \mathrm{~h}$. Samples were taken every hour. All cells were collected and total RNA was extracted by the hot phenol method [60]. First-strand cDNA was synthesised using a Primer Script RT reagent kit (CWBiotech, Beijing, China) according to the manufacturer's instructions. Both the uninduced and induced expression levels of HAC1 mRNA were estimated by PCR with the primer pair, HAC1-RT-F/HAC1-RT$\mathrm{R}$ (Table S1).

\subsection{Protein Extract Preparation and Western Blotting Analysis}

To investigate the phosphorylation levels of Hog1 and Slt2, yeast cells expressing Hog1-HA and Slt2-HA fusion proteins were first grown overnight in SC medium at $30^{\circ} \mathrm{C}$. Cells were then cultured in fresh SC medium to an $\mathrm{OD}_{600}$ of $0.8-1.0$, and treated with $50 \mu \mathrm{M}$ $\mathrm{CdCl}_{2}$ or $1 \mu \mathrm{g} / \mathrm{mL}$ TM for an additional $2 \mathrm{~h}$. To prepare protein extracts, cell cultures were first cooled in ice water for $10 \mathrm{~min}$ and cells were harvested by centrifugation at $4{ }^{\circ} \mathrm{C}$, then washed once with ice-cold water. Next, cells were resuspended in ice-cold lysis buffer [23] and vortexed with glass beads 10 times for $1 \mathrm{~min}$ each time. The lytic samples were centrifuged at $12,000 \mathrm{rpm}$ for $10 \mathrm{~min}$ at $4{ }^{\circ} \mathrm{C}$. Protein concentration was measured using a protein assay kit (Sangon Biotech, Shanghai, China) before samples were boiled with sample buffer (250 mM Tris- $\mathrm{HCl}$ pH 6.8, 10\% sodium dodecyl sulphate (SDS), $0.05 \%$ Bromophenol Blue, 50\% glycerol, 7.5\% DTT) for $5 \mathrm{~min}$.

To perform the Western blotting assay, samples were first analysed by $10 \%$ SDS-PAGE and transformed onto nitrocellulose membranes. Phosphorylation of Hog1-HA or Slt2-HA protein was immunodetected by phospho-p38 MAPK or phospho-p44/42 MAPK antibody (New England Biolabs, Beverly, MA, USA), respectively. Expression of Hog1-HA and Slt2-HA fusion proteins was detected by HA monoclonal antibody (Sangon Biotech).

\subsection{Statistical Analysis}

The SPSS Statistics version 19.0 is used to analyse the significant differences through its paired-samples $t$-test function. A value of $p<0.01$ is considered to be significant.

Supplementary Materials: The following are available online at https://www.mdpi.com/article/10 $.3390 /$ ijms22126169/s1.

Author Contributions: Conceptualization, Y.Z. and Y.D.; methodology, Y.Z.; software, S.L.; formal analysis, Y.Z. and Y.D.; investigation, J.W.; resources, Y.L.; writing-original draft preparation, Y.Z.; writing - review and editing, Y.D.; supervision, Y.D.; project administration, S.L.; funding acquisition, Y.Z. and Y.D. All authors have read and agreed to the published version of the manuscript. 
Funding: This work was funded by grants from the National Key R\&D Program of China (2019YFA0905502), the National Natural Science Foundation of China (21877053, 31601564), the Natural Science Foundation of Jiangsu Province (BK20181345), the Open Foundation of Jiangsu Key Laboratory of Industrial Biotechnology (KLIB-KF201807), and the Top-Notch Academic Programs Project of Jiangsu Higher Education Institutions.

Institutional Review Board Statement: Not applicable.

Informed Consent Statement: Not applicable.

Data Availability Statement: The data used to support the findings of this study are included within the article and the Supplementary Materials.

Conflicts of Interest: The authors declare no conflict of interest.

\section{References}

1. McGregor, D.B.; Baan, R.A.; Partensky, C.; Rice, J.M.; Wilbourn, J.D. Evaluation of the carcinogenic risks to humans associated with surgical implants and other foreign bodies-A report of an IARC Monographs Programme Meeting. International Agency for Research on Cancer. Eur. J. Cancer 2000, 36, 307-313. [CrossRef]

2. Cox, L.A., Jr. Quantifying potential health impacts of cadmium in cigarettes on smoker risk of lung cancer: A portfolio-ofmechanisms approach. Risk Anal. 2006, 26, 1581-1599. [CrossRef] [PubMed]

3. Stohs, S.J.; Bagchi, D. Oxidative mechanisms in the toxicity of metal ions. Free Radic Biol. Med. 1995, 18, 321-336. [CrossRef]

4. Fortuniak, A.; Zadzinski, R.; Bilinski, T.; Bartosz, G. Glutathione depletion in the yeast Saccharomyces cerevisiae. Biochem. Mol. Biol. Int. 1996, 38, 901-910. [PubMed]

5. Stohs, S.J.; Bagchi, D.; Hassoun, E.; Bagchi, M. Oxidative mechanisms in the toxicity of chromium and cadmium ions. J. Environ. Pathol. Toxicol. Oncol. 2001, 20, 77-88. [CrossRef] [PubMed]

6. Bertin, G.; Averbeck, D. Cadmium: Cellular effects, modifications of biomolecules, modulation of DNA repair and genotoxic consequences (a review). Biochimie 2006, 88, 1549-1559. [CrossRef] [PubMed]

7. Lam, Y.T.; Aung-Htut, M.T.; Lim, Y.L.; Yang, H.; Dawes, I.W. Changes in reactive oxygen species begin early during replicative aging of Saccharomyces cerevisiae cells. Free Radic Biol. Med. 2011, 50, 963-970. [CrossRef]

8. Nargund, A.M.; Avery, S.V.; Houghton, J.E. Cadmium induces a heterogeneous and caspase-dependent apoptotic response in Saccharomyces cerevisiae. Apoptosis 2008, 13, 811-821. [CrossRef]

9. Wang, S.H.; Shih, Y.L.; Ko, W.C.; Wei, Y.H.; Shih, C.M. Cadmium-induced autophagy and apoptosis are mediated by a calcium signaling pathway. Cell Mol. Life Sci. 2008, 65, 3640-3652. [CrossRef]

10. Xu, C.; Bailly-Maitre, B.; Reed, J.C. Endoplasmic reticulum stress: Cell life and death decisions. J. Clin. Investig. 2005, 115, 2656-2664. [CrossRef]

11. Orrenius, S.; Zhivotovsky, B.; Nicotera, P. Regulation of cell death: The calcium-apoptosis link. Nat. Rev. Mol. Cell Biol. 2003, 4, 552-565. [CrossRef] [PubMed]

12. Bonilla, M.; Cunningham, K.W. Mitogen-activated protein kinase stimulation of $\mathrm{Ca}(2+)$ signaling is required for survival of endoplasmic reticulum stress in yeast. Mol. Biol. Cell 2003, 14, 4296-4305. [CrossRef] [PubMed]

13. Hampton, R.Y. ER-associated degradation in protein quality control and cellular regulation. Curr. Opin. Cell Biol. 2002, 14, 476-482. [CrossRef]

14. Ron, D.; Walter, P. Signal integration in the endoplasmic reticulum unfolded protein response. Nat. Rev. Mol. Cell Biol. 2007, 8, 519-529. [CrossRef]

15. Cox, J.S.; Walter, P. A novel mechanism for regulating activity of a transcription factor that controls the unfolded protein response. Cell 1996, 87, 391-404. [CrossRef]

16. Travers, K.J.; Patil, C.K.; Wodicka, L.; Lockhart, D.J.; Weissman, J.S.; Walter, P. Functional and genomic analyses reveal an essential coordination between the unfolded protein response and ER-associated degradation. Cell 2000, 101, 249-258. [CrossRef]

17. Shuda, M.; Kondoh, N.; Imazeki, N.; Tanaka, K.; Okada, T.; Mori, K.; Hada, A.; Arai, M.; Wakatsuki, T.; Matsubara, O.; et al. Activation of the ATF6, XBP1 and grp78 genes in human hepatocellular carcinoma: A possible involvement of the ER stress pathway in hepatocarcinogenesis. J. Hepatol. 2003, 38, 605-614. [CrossRef]

18. Fernandez, P.M.; Tabbara, S.O.; Jacobs, L.K.; Manning, F.C.; Tsangaris, T.N.; Schwartz, A.M.; Kennedy, K.A.; Patierno, S.R. Overexpression of the glucose-regulated stress gene GRP78 in malignant but not benign human breast lesions. Breast Cancer Res. Treat. 2000, 59, 15-26. [CrossRef]

19. Maity, S.; Rajkumar, A.; Matai, L.; Bhat, A.; Ghosh, A.; Agam, G.; Kaur, S.; Bhatt, N.R.; Mukhopadhyay, A.; Sengupta, S.; et al. Oxidative homeostasis regulates the response to reductive endoplasmic reticulum stress through translation control. Cell Rep. 2016, 16, 851-865. [CrossRef]

20. Aragon, T.; van Anken, E.; Pincus, D.; Serafimova, I.M.; Korennykh, A.V.; Rubio, C.A.; Walter, P. Messenger RNA targeting to endoplasmic reticulum stress signalling sites. Nature 2009, 457, 736-740. [CrossRef] 
21. Kimata, Y.; Ishiwata-Kimata, Y.; Ito, T.; Hirata, A.; Suzuki, T.; Oikawa, D.; Takeuchi, M.; Kohno, K. Two regulatory steps of ER-stress sensor Ire1 involving its cluster formation and interaction with unfolded proteins. J. Cell Biol. 2007, 179, 75-86. [CrossRef] [PubMed]

22. Gardarin, A.; Chedin, S.; Lagniel, G.; Aude, J.C.; Godat, E.; Catty, P.; Labarre, J. Endoplasmic reticulum is a major target of cadmium toxicity in yeast. Mol. Microbiol. 2010, 76, 1034-1048. [CrossRef] [PubMed]

23. Chen, Y.J.; Feldman, D.E.; Deng, C.C.; Brown, J.A.; De Giacomo, A.F.; Gaw, A.F.; Shi, G.Y.; Le, Q.T.; Brown, J.M.; Koong, A.C. Identification of mitogen-activated protein kinase signaling pathways that confer resistance to endoplasmic reticulum stress in Saccharomyces cerevisiae. Mol. Cancer Res. 2005, 3, 669-677. [CrossRef] [PubMed]

24. Bilsland, E.; Molin, C.; Swaminathan, S.; Ramne, A.; Sunnerhagen, P. Rck1 and Rck2 MAPKAP kinases and the HOG pathway are required for oxidative stress resistance. Mol. Microbiol. 2004, 53, 1743-1756. [CrossRef]

25. Xiong, B.; Zhang, L.L.; Xu, H.H.; Yang, Y.; Jiang, L.H. Cadmium induces the activation of cell wall integrity pathway in budding yeast. Chem.-Biol. Interact. 2015, 240, 316-323. [CrossRef] [PubMed]

26. Jiang, L.H.; Cao, C.L.; Zhang, L.L.; Lin, W.; Xia, J.; Xu, H.H.; Zhang, Y. Cadmium-induced activation of high osmolarity glycerol pathway through its $\operatorname{Sln} 1$ branch is dependent on the MAP kinase kinase kinase Ssk2, but not its paralog Ssk22, in budding yeast. FEMS Yeast Res. 2014, 14, 1263-1272. [CrossRef]

27. Brewster, J.L.; de Valoir, T.; Dwyer, N.D.; Winter, E.; Gustin, M.C. An osmosensing signal transduction pathway in yeast. Science 1993, 259, 1760-1763. [CrossRef] [PubMed]

28. Bermejo, C.; Rodriguez, E.; Garcia, R.; Rodriguez-Pena, J.M.; de la Concepcion, M.L.R.; Rivas, C.; Arias, P.; Nombela, C.; Posas, F.; Arroyo, J. The sequential activation of the yeast HOG and SLT2 pathways is required for cell survival to cell wall stress. Mol. Biol. Cell 2008, 19, 1113-1124. [CrossRef]

29. Garcia, R.; Rodriguez-Pena, J.M.; Bermejo, C.; Nombela, C.; Arroyo, J. The high osmotic response and cell wall integrity pathways cooperate to regulate transcriptional responses to zymolyase-induced cell wall stress in Saccharomyces cerevisiae. J. Biol. Chem. 2009, 284, 10901-10911. [CrossRef]

30. Bicknell, A.A.; Tourtellotte, J.; Niwa, M. Late phase of the endoplasmic reticulum stress response pathway is regulated by Hog1 MAP kinase. J. Biol. Chem. 2010, 285, 17545-17555. [CrossRef]

31. Bernales, S.; McDonald, K.L.; Walter, P. Autophagy counterbalances endoplasmic reticulum expansion during the unfolded protein response. PLoS Biol. 2006, 4, e423. [CrossRef]

32. Yorimitsu, T.; Nair, U.; Yang, Z.; Klionsky, D.J. Endoplasmic reticulum stress triggers autophagy. J. Biol. Chem. 2006, 281, 30299-30304. [CrossRef]

33. Levin, D.E. Regulation of cell wall biogenesis in Saccharomyces cerevisiae: The cell wall integrity signaling pathway. Genetics 2011, 189, 1145-1175. [CrossRef] [PubMed]

34. Bonilla, M.; Nastase, K.K.; Cunningham, K.W. Essential role of calcineurin in response to endoplasmic reticulum stress. EMBO J. 2002, 21, 2343-2353. [CrossRef] [PubMed]

35. Babour, A.; Bicknell, A.A.; Tourtellotte, J.; Niwa, M. A surveillance pathway monitors the fitness of the endoplasmic reticulum to control its inheritance. Cell 2010, 142, 256-269. [CrossRef] [PubMed]

36. Scrimale, T.; Didone, L.; Bentley, K.L.D.M.; Krysan, D.J. The unfolded protein response is induced by the cell wall integrity mitogen-activated protein kinase signaling cascade and is required for cell wall integrity in Saccharomyces cerevisiae. Mol. Biol. Cell 2009, 20, 164-175. [CrossRef]

37. Levin, D.E. Cell wall integrity signaling in Saccharomyces cerevisiae. Microbiol. Mol. Biol. Rev. 2005, 69, 262-291. [CrossRef]

38. Torres-Quiroz, F.; Garcia-Marques, S.; Coria, R.; Randez-Gil, F.; Prieto, J.A. The activity of yeast Hog1 MAPK is required during endoplasmic reticulum stress induced by tunicamycin exposure. J. Biol. Chem. 2010, 285, 20088-20096. [CrossRef]

39. Proft, M.; Mas, G.; de Nadal, E.; Vendrell, A.; Noriega, N.; Struhl, K.; Posas, F. The stress-activated Hog1 kinase is a selective transcriptional elongation factor for genes responding to osmotic stress. Mol. Cell 2006, 23, 241-250. [CrossRef] [PubMed]

40. Proft, M.; Pascual-Ahuir, A.; de Nadal, E.; Arino, J.; Serrano, R.; Posas, F. Regulation of the Sko1 transcriptional repressor by the Hog1 MAP kinase in response to osmotic stress. EMBO J. 2001, 20, 1123-1133. [CrossRef]

41. Pelet, S.; Dechant, R.; Lee, S.S.; van Drogen, F.; Peter, M. An integrated image analysis platform to quantify signal transduction in single cells. Integr. Biol. 2012, 4, 1274-1282. [CrossRef]

42. Philip, B.; Levin, D.E. Wsc1 and Mid2 are cell surface sensors for cell wall integrity signaling that act through Rom2, a guanine nucleotide exchange factor for Rho1. Mol. Cell. Biol. 2001, 21, 271-280. [CrossRef]

43. Kim, K.Y.; Truman, A.W.; Levin, D.E. Yeast mpk1 mitogen-activated protein kinase activates transcription through Swi4/Swi6 by a noncatalytic mechanism that requires upstream signal. Mol. Cell. Biol. 2008, 28, 2579-2589. [CrossRef]

44. Watanabe, Y.; Takaesu, G.; Hagiwara, M.; Irie, K.; Matsumoto, K. Characterization of a serum response factor-like protein in Saccharomyces cerevisiae, Rlm1, which has transcriptional activity regulated by the Mpk1 (Slt2) mitogen-activated protein kinase pathway. Mol. Cell. Biol. 1997, 17, 2615-2623. [CrossRef] [PubMed]

45. Jung, U.S.; Levin, D.E. Genome-wide analysis of gene expression regulated by the yeast cell wall integrity signalling pathway. Mol. Microbiol. 1999, 34, 1049-1057. [CrossRef] [PubMed]

46. Pulido, M.D.; Parrish, A.R. Metal-induced apoptosis: Mechanisms. Mutat. Res. 2003, 533, 227-241. [CrossRef]

47. Mao, K.; Wang, K.; Zhao, M.; Xu, T.; Klionsky, D.J. Two MAPK-signaling pathways are required for mitophagy in Saccharomyces cerevisiae. J. Cell Biol. 2011, 193, 755-767. [CrossRef] [PubMed] 
48. Westfall, P.J.; Ballon, D.R.; Thorner, J. When the stress of your environment makes you go HOG wild. Science 2004, 306, 1511-1512. [CrossRef]

49. Jarup, L.; Berglund, M.; Elinder, C.G.; Nordberg, G.; Vahter, M. Health effects of cadmium exposure-a review of the literature and a risk estimate. Scand. J. Work Environ. Health 1998, 24 (Suppl. 1), 1-51.

50. Nair, A.R.; Lee, W.K.; Smeets, K.; Swennen, Q.; Sanchez, A.; Thevenod, F.; Cuypers, A. Glutathione and mitochondria determine acute defense responses and adaptive processes in cadmium-induced oxidative stress and toxicity of the kidney. Arch. Toxicol. 2015, 89, 2273-2289. [CrossRef]

51. Kitamura, M.; Hiramatsu, N. The oxidative stress: Endoplasmic reticulum stress axis in cadmium toxicity. BioMetals 2010, 23, 941-950. [CrossRef] [PubMed]

52. Posas, F.; Saito, H. Activation of the yeast SSK2 MAP kinase kinase kinase by the SSK1 two-component response regulator. EMBO J. 1998, 17, 1385-1394. [CrossRef] [PubMed]

53. Mattison, C.P.; Ota, I.M. Two protein tyrosine phosphatases, Ptp2 and Ptp3, modulate the subcellular localization of the Hog1 MAP kinase in yeast. Genes Dev. 2000, 14, 1229-1235. [PubMed]

54. Li, X.; Du, Y.R.; Siegel, S.; Ferro-Novick, S.; Novick, P. Activation of the mitogen-activated protein kinase, Slt2p, at bud tips blocks a late stage of endoplasmic reticulum inheritance in Saccharomyces cerevisiae. Mol. Biol. Cell 2010, 21, 1772-1782. [CrossRef]

55. Winzeler, E.A.; Shoemaker, D.D.; Astromoff, A.; Liang, H.; Anderson, K.; Andre, B.; Bangham, R.; Benito, R.; Boeke, J.D.; Bussey, H.; et al. Functional characterization of the S. cerevisiae genome by gene deletion and parallel analysis. Science 1999, 285, 901-906. [CrossRef]

56. Zhao, Y.; Du, J.; Xiong, B.; Xu, H.; Jiang, L. ESCRT components regulate the expression of the ER/Golgi calcium pump gene PMR1 through the Rim101/Nrg1 pathway in budding yeast. J. Mol. Cell Biol. 2013, 5, 336-344. [CrossRef]

57. Longtine, M.S.; McKenzie, A., 3rd; Demarini, D.J.; Shah, N.G.; Wach, A.; Brachat, A.; Philippsen, P.; Pringle, J.R. Additional modules for versatile and economical PCR-based gene deletion and modification in Saccharomyces cerevisiae. Yeast 1998, 14, 953-961. [CrossRef]

58. Madeo, F.; Frohlich, E.; Frohlich, K.U. A yeast mutant showing diagnostic markers of early and late apoptosis. J. Cell Biol. 1997, 139, 729-734. [CrossRef]

59. Ellis, C.D.; Wang, F.; MacDiarmid, C.W.; Clark, S.; Lyons, T.; Eide, D.J. Zinc and the Msc2 zinc transporter protein are required for endoplasmic reticulum function. J. Cell Biol. 2004, 166, 325-335. [CrossRef]

60. Kohrer, K.; Domdey, H. Preparation of high molecular weight RNA. Methods Enzymol. 1991, 194, $398-405$. 